\title{
1. Introduction: de-centering state making
}

\author{
Jens Bartelson, Martin Hall and Jan Teorell
}

\section{INTRODUCTION}

The overarching ambition of this volume is to bring about a de-centering of state making by shifting the focus beyond the emergence of states in early modern Western Europe. This dual focus has been pervasive among scholars of international relations, comparative politics and historical sociology. Students of international relations have long located the origin of the modern state and the international system to the Peace of Westphalia in 1648, and although this once widespread view has been thoroughly criticized and even relegated to the realm of myth, those who debate the issue of when states emerged nevertheless still agree that this happened in Western Europe before it could happen elsewhere (Ruggie 1993; Spruyt 1994; Croxton 1999; Osiander 2001; Teschke 2003; Philpott 2001; Beaulac 2004; Nexon 2009). Such a focus on early modern Western Europe has been equally pervasive among historical sociologists, many of whom have traced the emergence of states to the self-reinforcing confluence of warfare, the centralization of authority and fiscal capacity from the late Middle Ages to the modern period (Tilly 1975, 1985, 1992; Hintze 1975). Scholars of comparative politics have not deviated far from this general picture (Rokkan 1973, 1975; Downing 1992; Ertman 1997).

Given their common historical and geographical focus, scholars of international relations have portrayed the spread of the sovereign state as an unintended outcome of European expansion on other continents, while scholars of comparative politics and historical sociologists have assumed or implied that a similar confluence of social and political factors that once led to the formation of states in Western Europe will produce similar results in other geographic contexts. Our ambition is to de-center these accounts of state making by focusing on developments in other historical and geographic contexts in order to generate new insights about the nature and causes of state making. But rather than trying to refute the above-mentioned theories, we want to challenge their claims to validity 
by probing their scope conditions and inquire into how well their core assumptions travel into other historical and geographical contexts. It is our belief that in order to add fresh insights into the nature and causes of state making, such a de-centering has to address its conceptual, theoretical and empirical aspects simultaneously.

First, it is necessary to unpack and sometimes modify standard definitions of the concept of the state in order to make it better fit with other experiences of statehood. Second, it is necessary to revise conventional explanations of state making in order to make sense of cases that otherwise would appear idiosyncratic or anomalous. Third, it is necessary to use insights from such idiosyncratic and anomalous cases in order to identify alternative paths to statehood and more general explanations of state making. In sum, we cannot hope to make new sense of anomalous cases unless we are prepared to revise standard assumptions about the causes of state making, and we cannot revise these assumptions unless we first probe into definitions of the state concept.

Such questioning has to take the historical meanings of the state concept into consideration, but also strike a balance between historically sensitive uses of this concept and more generic ones. An inquiry into the changing meaning of the concept of the state gives us a first inroad to a historical decentering. Although some preconditions of sovereign statehood were present in Europe well before the seventeenth century, such as claims to supreme authority, another typical characteristic of the modern state - its territorial boundedness - had to wait until the following century before it was translated into facts on the ground and entrenched in legal definitions of the state (Branch 2013; Elden 2013; Maier 2016). Still other characteristics of the modern state are of an even more recent vintage: the rise and spread of the notion that political authority ought to be externally independent and later also congruent with a people or nation in order to be internally legitimate is something we owe to the Age of Revolutions and its aftermath (Armitage 2007; Armitage and Subrahmanyam 2009). Only after these requirements had been fulfilled and sedimented into lexical definitions of the concepts of sovereignty and state did it become possible to ask how and why this peculiar form of political association had come into being, and to trace the processes through which political authority had been centralized, territorially demarcated and eventually merged with that of a bounded community backwards in time. Given these background conditions, the historical and geographical limits of modern theories of state making are hardly surprising and all the more revealing. From this it follows that the first step toward a conceptual de-centering of the state would be to unpack those components before we use the state concept in a generic or transhistorical sense to understand and explain experiences of statehood in other times and places. 
Thus, it is fully possible to use the concept of the state in a meaningful and coherent way without implying that political authority and community are territorially congruent. Even if such creative uses amount to stretching the concept of the state beyond established connotations, such stretching can indeed be productive when undertaken for the purpose of capturing cases of political rule that would otherwise fall outside the scope of analysis. Several chapters in this volume capitalize on this possibility, by inquiring into political institutions and modes of governance that have little to do with what allegedly happened in Westphalia or during the Age of Revolutions, but all the more to do with how political and social forces produced altogether different constellations of political authority and community outside the Western European core, and at other points in time.

What goes for the historical context of state theorizing also goes for its geographical context. Theories of state making not only reflect the fact that the concept of the state has a distinct pedigree that reflects unique European experiences of statehood, but also the fact that most empirical studies of state formation have been firmly centered on the European context. But although there is no shortage of studies that criticize the Eurocentric tendencies of academic international relations and historical sociology, there have been few attempts to date to bring such criticism to bear on theories of state making in ways that would help to revise them accordingly (Thies 2004; Bhambra 2007; Jones 2006; Taylor and Botea 2008; Kayaoglu 2010; Hobson 2012; Kaspersen and Strandsbjerg 2017). This volume responds to such criticism not by debunking existing theories of state making on grounds of their Eurocentrism, but instead by exploring why some assumptions about state making travel to other geographical contexts with no apparent loss of explanatory power, while others seem to lose their bite as soon as they are removed from their context of origin. Inquiring into the preconditions of state making in other geographical contexts can not only help us expose the limits of extant theorizing, but also contribute to general insights about the causes of state making. The contributions to this volume are guided by the general assumption that the more or less exclusive focus on Western European state making has introduced a strong bias into theories of state making, which in turn has had profound and detrimental effects on the field of inquiry as a whole. From this follows an ambition to question the received view according to which the emergence of states outside Europe was the result of the diffusion of sovereign statehood through the practices of imperialism and colonialism, and instead to emphasize the sui generis character of these processes by situating them in a wider context of different and competing forms of human association. 
Taken together, the historical and geographical de-centering of state making makes the contingency of the modern state apparent. Although the state remains the predominant locus of political authority and community in the modern world, this predominance is relatively recent and, arguably, also increasingly precarious, given that many of the preconditions behind its rise to prominence are being challenged by global and transnational forces (Sassen 2008; Ferguson and Mansbach 2004; Agnew 2009). But rather than pondering whether the state is here to stay or will fade away, we would instead like to emphasize the fact that for most of its history in Europe and elsewhere, states have coexisted with other and sometimes rival forms of political authority. This makes it imperative to understand how and explain why the state once rose to prominence in competition with its most obvious contenders such as empires and city-states, but also how the transition from empires to states often made a detour through hybrid forms characterized by divided sovereignty, plural and overlapping jurisdictions, and fuzzy boundaries (Benton 2002; Adelman 2006; Benton 2009).

Hence, and in contrast to those accounts of state making that portray state making as a series of interlocking causal mechanisms and processes, sometimes to the point of making the triumph of the state over alternative forms of political rule look inevitable, contributors to this volume emphasize the historical and geographical contingency of these mechanisms and processes. Although contributors to this volume do not doubt that the making of states elsewhere might owe much to the same interlocking causes that drove European state making, rather than trying to identify a single pathway to statehood by assuming that these causes constitute a coherent package, they take their disentangling to be necessary in order to overcome the Eurocentrism of conventional accounts.

The question of war and its role in state making is especially pertinent in this regard: if war between groups gives rise to states in some contexts but not in others, how is this pattern of variation to be accounted for? Conversely, how are we to understand those instances in which states did emerge without being accompanied by warfare? The fact that similar processes sometimes produce different results under different conditions, and that different processes sometimes produce similar results, is a strong reason in favor of contextualizing such assumptions. 


\section{OVERCOMING ANACHRONISM AND EUROCENTRISM}

In order to overcome anachronism and Eurocentrism, we believe that it is necessary to bridge the long-standing gap between endogenous and exogenous explanations of state making, and, by implication, between international and comparative perspectives on this development. While students of international relations typically approach the state from the outside in, students of comparative politics proceed the other way around. This division of intellectual labor has meant that students of comparative politics have tended to take for granted precisely what students of international relations find problematic, as well as conversely. Whereas the former have assumed that the international context in which the making of states takes place is given, the latter have often assumed that states are present in some embryonic form.

This lacuna becomes even more pertinent when it comes to explaining how states acquire the capacity to act with relative autonomy, internally as well as externally. Whereas students of international relations have often taken such agency for granted and attributed it to the state as a whole (for example, Lake 2008), historical sociologists and students of comparative politics have instead focused on how distinct actors within the state have achieved a capacity to act autonomously in a domestic setting (for example, Evans et al. 1985; Vu 2010). Thus there seems to be an insurmountable gap between these two understandings of state and its agency, and extant attempts to bridge this gap have done so by turning it into either a philosophical or a historical problem. To those who have taken the former route, accounting for state agency is a matter of explaining how states become actors by virtue of embodying a collective consciousness, or as a result of an aggregation of this capacity from the individual and group levels upward (Wendt 2004; Wight 2006; List and Pettit 2011). To those who have taken the latter route, it has either been a matter of explaining how states acquired their capacity to act as a result of interaction within a nascent international system, or by arguing that their capacity for autonomous action is a consequence of the success with which theories of legal personality have been translated into political practice (Giddens 1985; Skinner 2009; Bartelson 2015; Holland 2017).

Our take on this problem is slightly different. By situating the emergence of states and the international system in a wider context of interaction and interdependence between different forms of political association, we assume that modern states and the international system are best understood as being co-constituted in time, and that this process of coconstitution should be approached from a diachronic perspective. At the 
most general level, and in contrast to accounts that trace the rise of states to a struggle for independence against papal or imperial authority during the late Middle Ages, or that locate the origins of states to the fragmentation of Christian unity that resulted from the Reformation and the wars of religion, we conceive of state making as a process through which bounded sovereignty was first differentiated from unbounded forms of political rule before it superseded the latter. Although this process started in early modern Europe, it was significantly accelerated and eventually also globalized as a result of the intensified interaction and technological advances that characterized the coming centuries (Bayly 2003; Osterhammel 2014). This focus on historical co-constitution is another reason why we should avoid packing too much content into our definitions of state and sovereignty, and leave as much as possible of that content to be decided by historical inquiry. For example, although there are strong reasons to keep the internal and external dimensions of sovereign statehood distinct for the sake of analytical clarity, an emphasis on co-constitution would not only entail that these dimensions are two sides of the same coin, but also that the distinction between them is itself an outcome of the process through which unbounded and bounded forms of rule were differentiated. Hence a focus on co-constitution makes it possible to explore the interplay between hallmark characteristics of domestic sovereignty such as coercive capacity and defining aspects of external sovereignty such as international recognition, without according primacy to any of them, thereby avoiding the chicken-and-egg quality of previous philosophical and historical attempts to bridge the gap between these dimensions.

But the gap between international and comparative perspectives on state making is also a result of different methodological predispositions. Whereas those relatively few and predominantly European students of international relations who have taken an interest in state making share ideographic and interpretive ambitions, students of comparative politics are more inclined to use nomothetic theorizing and quantitative methods to substantiate their claims. While this methodological divide has been much debated, it has proved difficult to bridge in more principal terms. Yet irrespective of these differences, qualitative and quantitative approaches share similar views as to what constitutes the basic rules of logical and causal inference. This volume starts from such common ground, and takes a pragmatic approach to whatever differences that remain. Beyond a mere lip service to the mantra of mixed methods, many contributors to this volume have been able to integrate results from both comparative politics and academic international relations by downplaying or simply ignoring such differences. Much the same goes for the corresponding tension between the ambition to understand and the ambition to explain polit- 
ical phenomena. Contributors to this volume assume or imply that these ambitions complement rather than contradict each other. For example, understanding how states emerged is a necessary precursor to explaining why they emerged, and explaining why states did emerge typically presupposes an understanding of how the international system or society within which they are embedded came into being, and how it compelled states to adopt similar strategies and institutional characteristics in order to survive the sometimes fierce competition for security, wealth and standing characteristic of this system.

Downstream from these methodological differences, but all the more challenging, are incommensurable views about the makeup of the sociopolitical world that animate theories of state making. Whereas the study of the state within international relations has gravitated toward an ideational and discursive understanding of its nature in recent decades, the study of comparative politics has by and large retained a materialist and positivist take on the same phenomena. Scholars of a constructivist bent are likely to conceptualize the state as a social construct, and then analyze the discursive practices that have brought it into being as a social fact. Scholars committed to a materialist view are more likely to conceptualize the state in institutional terms, and then analyze the complex chain of causes that have made the state a brute fact of political life. While overcoming the tension between these different views falls far outside the purview of the present volume, it is evident that state making once occurred in blissful ignorance of any such lacuna between language and world. But if states have been welded together out of disparate material and symbolic elements, overcoming the above tension seems even more desirable. It is therefore imperative to further explore the ways in which different conceptions of the state were turned into facts on the ground, and how such facts on the ground were fed back into conceptions of the state in the attendant quest for legitimacy. As we end by suggesting in the concluding chapter, exploring the interface between material and ideational factors in state making represents a major intellectual challenge that calls for a broad synthesis between the traditional concerns of comparative politics and international relations.

\section{WHAT THIS VOLUME CONTAINS}

The different parts of this volume contribute to this de-centering in different ways. In addition to an introduction by the editors, the book consists of four main parts. Part I is concerned with those instances of state making that produced results that appear idiosyncratic from a Eurocentric perspective. Part II problematizes the positive correlation 
between war or preparation for war and state making. Part III deals with state-making processes at a systemic level of analysis, and how systemic factors in turn condition state-making processes at the unit level. Part IV takes a step back and critically discusses whether it is at all possible to decenter state making, and, in addition to distilling some general conclusions from the first three parts, presents some challenges for future research.

In Part I - What makes a state? - three chapters explore the driving forces of state making in non-early modern European settings. In Chapter 2, Martin Hall studies 2200 years of state making on the Eurasian steppe. His main argument is that states developed on the steppe as a response to Chinese attempts to monopolize or delimit trade. Times of crisis on the steppe - be it caused by environmental or climatic disruptions, massive violence, or something else - would allow for social mobility, and new military elites could free themselves from traditional tribal authority and set up embryonic states. The new states needed enormous resources in order to maintain standing armies and to foster and reward loyal followers. Warfare and raiding would not have supplied the states with these resources, as the spoils of raiding were shared among all participants. Fearing any concentration of power on the steppe, the Chinese would attempt to limit the supply of resources to the developing states by restricting trade. Steppe states, then, were dependent on securing an open international economy rather than securing territory or sovereignty. Hall's theoretical conclusion is that the crucial difference between European and Steppe state making is that the former took place in a pre-existing international system, whereas the latter took place in a pre-existing international political economy. Given these two different initial conditions, similar mechanisms and logics played out differently, and created different kinds of states and different international orders. 'The Westphalian system' is a criticized but heuristic shorthand for the context in which European state making took place; 'the Silk Road' could serve as a similarly heuristic misnomer for the Eurasian steppe.

In Chapter 3 Ted Svensson queries to what was India's federalism a response. Arguing that Indian democracy is well researched, the other building bloc of Indian state making - federalism - is both understudied and less well understood. Being formed by both the provinces of British India and a range of princely states with varying degrees of sovereignty and capacities, it was not at all clear that India would become a federal state rather than some form of 'Indian Union.' The chapter aims to redress the received wisdom on British direct and indirect rule; a wisdom that reifies the distinction between the two and that further collapses the complexity of rule and sovereignty into one manageable category (this theme is further developed by Learoyd in Chapter 8, this volume). Second, Svensson stud- 
ies debates on federalism in India before and after independence, in order to qualify and expand upon exiting theories of federalism.

In Chapter 4 Jonathan Hanson, focusing on contemporary developing states, seeks to synthesize a large literature that explores the question of why states form and become strong in some cases while remaining weak and fragile in others. Hanson suggests that the literature has identified three main challenges that would-be state builders are facing: the provision of security, the creation of political community and the revenue imperative. He then develops a range of testable empirical propositions that can be subsumed under these challenges. A key purpose of this chapter is not to privilege one of these challenges over the others - such as war, for instance. Instead, Hanson seeks to provide an integrated and holistic model in which the causal arguments from various theories are not treated as mutually exclusive, but rather operative in different contexts. A key finding in the chapter is that, in the post-World War II era, internal factors such as levels of social diversity and democracy are more closely associated with changes in state capacity than are external threats. This finding is consistent - albeit not identical - with the conclusions arrived at by Goenaga and von Hagen-Jamar in this volume. On a similar note, Annika Björkdahl, in her contribution to this volume (Chapter 7), provides a qualitative case study whose conclusions are consistent with Hanson's arguments regarding the creation of political community.

In Part II - What states does war make? - three chapters focus on war and competition as driving forces of state making, and the impact of war on what kinds of states are formed. In Chapter 5, Agustín Goenaga and Alexander von Hagen-Jamar accomplish two things. First, they provide an extensive and careful review of the bellicist theory of state making. They identify four main bones of contention in this literature: whether state making is a fiscal contract or a protection racket; whether the causal mechanism is evolutionary selection or structural transformation; whether war has actually to take place or if the threat of war is enough; and, finally, whether the temporal structure is punctuated or incremental. Goenaga and von Hagen-Jamar then hone in their critical assessment of bellicist arguments on the nineteenth and twentieth centuries, noting how conceptual confusion, problems of data availability and measurement validity, together with debates on scope conditions were eventually 'resolved' in favor of the bellicist view. Two things stand out in their analysis. First, how the bellicist theory has been transformed from a general theory to a set of middle-range theories. Second, why it is no longer feasible to claim that the bellicist theory in its general formulation can be applied to the post-1789 period. Goenaga and von Hagen-Jamar then introduce empirical models intended to test the relationship between military rivalry and war, and the 
level of taxation in the nineteenth and twentieth centuries. They find little evidence of a consistent relationship between wars or rivalries and levels of taxation.

In Chapter 6, deploying a comparative international systems approach, Charles Butcher and Ryan Griffiths start out by defining six types of sovereign bargains that might obtain between imperial centers and subordinate polities. Not unlike Arthur Learoyd's contribution to this volume (Chapter 8), they argue that between the two extremes of full sovereignty and absorption (no sovereignty) sovereignty is a matter of degree: tributary, heteronomy, suzerainty and hierarchy. What kind of relationship an imperial center will have to subordinate polities depends on whether the subordinate polity retains autonomy in foreign affairs, and whether resources that flow to the center do so through transfers or through direct extraction. Butcher and Griffiths then go on to propose that international competition mitigated by interaction capacity determines which arrangement is likely to be selected. They hypothesize that in low-density environments, increased international competition will result in bigger but decentralized states, or in suzerain relations. In high-density environments, however, increased competition is more likely to give rise to absorption, or hierarchical or heteronymous relations. These predictions are borne out in a comparative case study of the Oyo Empire and the Mysore Kingdom, leading the authors to conclude that interaction capacity determines what kind of state international competition is likely to produce.

In Chapter 7, Annika Björkdahl focuses on the non-material side of state making. While most of the state-making literature is focused on the role of war and resource extraction, Björkdahl explores the role of imaginaries and performances in state-making projects in post-war contexts. Studying three divergent state-making projects in former Yugoslavia - Bosnia Herzegovina, Republika Srpska and Herceg-Bosna - Björkdahl argues that, in these three cases, states were imagined in ethno-nationalistic terms. Historical narratives and myths were carefully selected and fed into these imaginaries in order to legitimize them. Downstream from the imaginaries, Björkdahl identifies spheres of performances that turned these imaginaries into tangible realities: the war-making performance of ethnic cleansing was cemented in the peace-making performances of the 1995 Dayton Peace Accords, setting the stage for other state-making performances such as referenda, constitution writing and so forth. Everyday performances of the ethno-nationalistic imaginaries involved such banal practices as changing residential patterns, separate football clubs, separate bus lines and weather forecasts.

In Part III of the volume - State making and international society Chapters 8 and 9 situate state making in the burgeoning international society of the nineteenth century. Both chapters take different notions of 
semi-sovereignty seriously, thereby rejecting the earlier and legalist view according to which sovereignty is an attribute that either is present or not, and a state cannot be said to exist in its absence.

In Chapter 8 Arthur Learoyd sets out to explore a range of semisovereign polities during the long nineteenth century. Distinguishing first between full sovereignty, semi-sovereignty and non-sovereignty, and then between kinds of semi-sovereign entities, Learoyd seeks to account for the variation among the latter. In his account, four distinct social logics were operative in the creation of semi-sovereignty. Although international law provided much impetus in this regard, management, suzerainty and cultural differentiation also mattered. Yet there was never the case that any single logic determined the nature of any semi-sovereign polity. Learoyd thus takes unit differentiation seriously and argues for a configurational approach to state making. His contribution is one example of the middlerange approaches that Goenaga and von Hagen-Jamar (Chapter 5) take to be characteristic of the recent debate about state making.

In Chapter 9 Ellen Ravndal, focusing on membership in international organizations, argues that contrary to widespread belief such membership has strengthened state sovereignty rather than limited or undermined it. In the nineteenth century, semi-sovereign states could strengthen their claim to both external and internal sovereignty by joining different international organizations. Ravndal identifies several ways in which membership strengthened international sovereignty by reinforcing the fundamental principle of recognition, as well as how such membership reinforced the domestic authority structures of these aspiring states. Such membership signaled a commitment to modernity and to technological and institutional development, and these organizations were also sites of learning and providers of services such as international patents. As such, Ravndal's analysis nicely supplements the social logics cited by Learoyd.

In the concluding Part IV, Janis Grzybowski (Chapter 10) critically discusses the possibilities and limits of a de-centering of state making, while Jens Bartelson and Jan Teorell (Chapter 11) draw some general conclusions from the contributions, and on the basis of these point out some challenges for future research on state making.

Grzybowski argues that any attempt at de-centering state making paradoxically recenters the state, either from a domestic or international point of view. Studies that temporally de-center state making - studies that move away from the conventional focus on early modern Europe and focus on other experiences of statehood - tend to reify some notion of an international system, whereas work that aspires to de-center state making geographically, by venturing outside the European context, tend to naturalize a sharp distinction between state and non-state. Grzybowski 
thereby suggests that the concept of the state is both given and inescapable, and that our attempts to de-center the state therefore are double-edged. In the end, however, Grzybowski concedes that such de-centering is still more viable and intellectually promising than any available alternative.

In the concluding chapter, Jens Bartelson and Jan Teorell briefly summarize the main upshots of individual chapters, and how their ambitions to de-center state making have affected the ways in which the state is conceptualized, how the making of states is theorized, and how the looming gap between the study of comparative politics and international relations best can be bridged in the interest of achieving a better understanding of processes of state making in early modern Europe and elsewhere. They end up suggesting that future students of state making ought to strike a balance between settling the content of the state concept by means of stipulative definitions on the one hand, and treating that content as spatiotemporally variable on the other. They also propose that the importance of factors other than war should be more systematically investigated, and that this would necessitate a more discriminatory approach to reversible versus irreversible causal mechanisms, as well as a much clearer specification of counterfactuals: in order to understand what state making $i s$, we need to understand what it is not. Finally, they suggest that the lingering tension between materialistic and ideational understandings of the state and the state-making process must be overcome in order to fully grasp their nature, and that this necessitates a sustained engagement with disciplinary differences, as well as a willingness to incorporate insights from research traditions that have been less bothered by ontological tensions when defining their subject matter and objects of inquiry.

\section{REFERENCES}

Adelman, Jeremy (2006), Sovereignty and Revolution in the Iberian Atlantic, Princeton: Princeton University Press.

Agnew, John (2009), Globalization and Sovereignty, Lanham: Rowman \& Littlefield Publishers.

Armitage, David (2007), The Declaration of Independence: A Global History, Cambridge, MA: Harvard University Press.

Armitage, David and Sanjay Subrahmanyam (eds) (2009), The Age of Revolutions in Global Context, c. 1760-1840, Basingstoke: Palgrave Macmillan.

Bartelson, Jens (2015), 'Sovereignty and the personality of the state,' in Robert Schuett and Peter M.R. Stirk (eds), The Concept of the State in International Relations: Philosophy, Sovereignty, and Cosmopolitanism, Edinburgh: Edinburgh University Press, pp. 81-107.

Bayly, Christopher A. (2003), The Birth of the Modern World, 1780-1914, Oxford: Wiley-Blackwell. 
Beaulac, Stéphane (2004), The Power of Language in the Making of International Law: The Word Sovereignty in Bodin and Vattel and the Myth of Westphalia, Leiden: Martinus Nijhoff Publishers.

Benton, Lauren (2002), Law and Colonial Cultures: Legal Regimes in World History, 1400-1900, Cambridge: Cambridge University Press.

Benton, Lauren (2009), A Search for Sovereignty: Law and Geography in European Empires, 1400-1900, Cambridge: Cambridge University Press.

Bhambra, Gurminder (2007), Rethinking Modernity: Postcolonialism and the Sociological Imagination, Basingstoke: Palgrave Macmillan.

Branch, Jordan (2013), The Cartographic State: Maps, Territory, and the Origins of Sovereignty, Cambridge: Cambridge University Press.

Croxton, Derek (1999), 'The Peace of Westphalia of 1648 and the origins of sovereignty,' The International History Review, 21 (3), 569-91.

Downing, Brian (1992), The Military Revolution and Political Change: Origins of Democracy and Autocracy in Early Modern Europe, Princeton: Princeton University Press.

Elden, Stuart (2013), The Birth of Territory, Chicago: University of Chicago Press.

Ertman, Thomas (1997), Birth of the Leviathan: Building States and Regimes in Medieval and Early Modern Europe, Cambridge: Cambridge University Press.

Evans, Peter, Dietrich Rueschemeyer and Theda Skocpol (eds) (1985), Bringing the State Back In, Cambridge: Cambridge University Press.

Ferguson, Yale H. and Richard W. Mansbach (2004), Remapping Global Politics: History's Revenge and Future Shock, Cambridge: Cambridge University Press.

Giddens, Anthony (1985), The Nation-State and Violence, Berkeley: University of California Press.

Hintze, Otto (1975), The Historical Essays of Otto Hintze, ed. Felix Gilbert, Oxford: Oxford University Press.

Hobson, John M. (2012), The Eurocentric Conception of World Politics: Western International Theory, 1760-2010, Cambridge: Cambridge University Press.

Holland, Ben (2017), The Moral Person of the State, Cambridge: Cambridge University Press.

Jones, Branwen Gruffydd (ed.) (2006), Decolonizing International Relations, Lanham: Rowman \& Littlefield.

Kaspersen, Lars Bo and Jeppe Strandsbjerg (eds) (2017), Does War Make States? Investigations of Charles Tilly's Historical Sociology, Cambridge: Cambridge University Press.

Kayaoglu, Turan (2010), 'Westphalian Eurocentrism in international relations theory,' International Studies Review, 12 (2), 193-217.

Lake, David (2008), 'The state and international relations,' in C. Reus-Smit and D. Snidal (eds), The Oxford Handbook of International Relations, Oxford: Oxford University Press.

List, Christian and Philip Pettit (2011), Group Agency: The Possibility, Design, and Status of Corporate Agents, Oxford: Oxford University Press.

Maier, Charles S. (2016), Once Within Borders: Territories of Power, Wealth, and Belonging Since 1500, Cambridge MA: Harvard University Press.

Nexon, Daniel H. (2009), The Struggle for Power in Early Modern Europe: Religious Conflict, Dynastic Empires, and International Change, Princeton: Princeton University Press.

Osiander, Andreas (2001), 'Sovereignty, international relations, and the Westphalian myth,' International Organization, 55 (2), 251-87. 
Osterhammel, Jürgen (2014), The Transformation of the World: A Global History of the Nineteenth Century, Princeton: Princeton University Press.

Philpott, Daniel (2001), Revolutions in Sovereignty: How Ideas Shaped Modern International Relations, Princeton: Princeton University Press.

Rokkan, Stein (1973), 'Cities, states, and nations: a dimensional model for the study of contrasts in development,' in S. Eisenstadt and S. Rokkan (eds), Building States and Nations, vol. I, Beverly Hills and London: Sage Publications.

Rokkan, Stein (1975), 'Dimensions of state formation and nation-building: a possible paradigm for research on variations within Europe', in C. Tilly (ed.), The Formation of National States in Western Europe, Princeton: Princeton University Press.

Ruggie, John Gerard (1993), 'Territoriality and beyond: problematizing modernity in international relations,' International Organization, 47 (1), 139-74.

Sassen, Saskia (2008), Territory, Authority, Rights: From Medieval to Global Assemblages, Princeton: Princeton University Press.

Skinner, Quentin (2009), 'A genealogy of the modern state', Proceedings of the British Academy, vol. 162.

Spruyt, Hendrik (1994), The Sovereign State and its Competitors: An Analysis of Systems Change, Princeton: Princeton University Press.

Taylor, Brian and Roxana Botea (2008), 'Tilly tally: war-making and state-making in the contemporary Third World,' International Studies Review, 10 (1), 27-56.

Teschke, Benno (2003), The Myth of 1648: Class, Geopolitics, and the Making of Modern International Relations, London: Verso.

Thies, Cameron (2004), 'State building, interstate and intrastate rivalry: a study of post-colonial developing country extractive efforts, 1975-2000,' International Studies Quarterly, 48 (1), 53-72.

Tilly, Charles (1975), 'Reflections on the history of European state-making,' in C. Tilly (ed.), The Formation of National States in Western Europe, Princeton: Princeton University Press.

Tilly, Charles (1985), 'War making and state making as organized crime,' in P. Evans, D. Rueschemeyer and T. Skocpol (eds), Bringing the State Back In, Cambridge: Cambridge University Press.

Tilly, Charles (1992), Coercion, Capital, and European States, AD 990-1992, Cambridge and Oxford: Blackwell.

Vu, Tuong (2010), 'Studying the state through state formation,' World Politics, 61 (1), 148-75.

Wendt, Alexander (2004), 'The state as person in international theory,' Review of International Studies, 30 (2), 289-316.

Wight, Colin (2006), Agents, Structures, and International Relations: Politics as Ontology, Cambridge: Cambridge University Press. 